\title{
A field study on the load sharing behavior of a micropiled raft underpinned by a waveform micropile
}

\author{
Chengcan Wang, Jin-Tae Han, and Seokjung Kim
}

\begin{abstract}
A waveform micropile (WMP) uses the jet-grouting method to generate shear keys along the pile shaft for improving shaft resistance and cost efficiency. In this study, field loading tests were performed to characterize the load sharing behavior upon inclusion of a WMP in a group of four micropiles. First, single-pile compressive loading tests were conducted on three WMPs and five type A micropiles (MP). Subsequently, a group-pile loading test was performed on a piled raft comprising $2 \times 2$ MPs and a central WMP. The load-settlements, axial stiffnesses, and load transfer mechanisms of individual MPs were analyzed during the tests, including the short- and long-term effects of the axial stiffnesses of the MPs on the load sharing ratio of the micropiled raft. The single-pile loading test results revealed that the shear keys along the WMPs caused its bearing capacities and axial stiffnesses to be 1.5 times and 2-5 times higher than those of MPs, respectively. In the micropiled-raft loading test, the load sharing ratios of the MPs increased with their axial stiffnesses, and the highest load sharing capacity was exhibited by the WMP, which constituted 30\% of the total load and 2-3 times that of MPs. Moreover, the influence of raft on the load-sharing capacity should be considered as well.
\end{abstract}

Key words: waveform micropile, pile axial stiffness, load sharing ratio, micropiled raft, long-term behavior.

Résumé : Un micropieu à forme d'onde (WMP) emploie la méthode de jet grouting afin de générer des clés de cisaillement le long de l'arbre du pieu et ainsi améliorer la résistance de l'arbre et la rentabilité. Dans le cadre de cette recherche, on a effectué des essais de chargement sur le terrain afin de caractériser le comportement de partage de la charge lors de l'inclusion d'un WMP au sein d'un groupe de quatre micropieux. Au départ, des essais de chargement en compression sur un seul pieu ont été effectués sur trois WMP et cinq micropieux de type A (MP). Par la suite, on a effectué un essai de chargement de groupe sur un radeau de pieux comprenant $2 \times 2$ MP et un WMP central. Les mécanismes d'installation de la charge, les rigidités axiales et les mécanismes de transfert de charge des MP individuels ont été analysés au cours des essais, y compris les effets à court et à long terme des rigidités axiales des MP sur le rapport de partage de la charge du radeau de micropieux. Selon les résultats de l'essai de chargement d'un seul pieu, les clés de cisaillement le long des WMP ont provoqué des capacités de charge et des rigidités axiales 1,5 fois et 2-5 fois plus élevées que celles des MP, respectivement. Au cours de l'essai de chargement par micropieux, les rapports de partage de la charge des MP ont augmenté avec leurs rigidités axiales, et la capacité de partage de la charge la plus élevée a été présentée par le WMP, qui a constitué 30 \% de la charge totale et 2 à 3 fois celle des MP. Il faut également tenir compte de l'influence du radeau sur la capacité de partage de la charge. [Traduit par la Rédaction]

Mots-clés : micropieu à forme d'onde, rigidité axiale du pieu, rapport de répartition de la charge, micropieu-raft, comportement à long terme.

\section{Introduction}

Owing to the rapid population growth and limited land in urban cities, the vertical extension of existing buildings is one of the possible alternatives to improve and to increase the use of such buildings; the Government of South Korea has published guidelines stating that old existing apartment buildings taller than 14 and 15 floors can be extended vertically by adding 2 and 3 floors, respectively (MOLIT 2013). However, such extensions are likely to impose additional loads on the existing foundations, thereby exceeding the allowable bearing capacities. Therefore, underpinning with new piles is one of the effective methods to ensure the safety and stability of the structure.
In general, micropiles are widely used to underpin existing foundations (Bruce 1989), and they can be adopted to resist partial loads from the structure to reduce the loads transferred to the existing piles. Han and Ye (2006) performed a field loading test for investigating the micropile underpinning performance in a shallow foundation and reported that the micropiles supported approximately $70 \%-80 \%$ of the additional loads. Based on the experimental results, they proposed a simplified design procedure. Subsequently, El Kamash and Han (2017) conducted a parametric study to examine the micropile-soil-plate interaction and the load transfer mechanisms of soils and micropiles based on several factors. They reported that the initial pressure ratio for underpinning and the micropile length pose a more significant impact

Received 2 September 2020. Accepted 19 November 2021.

C. Wang. POWERCHINA Huadong Engineering Corporation Limited, 201 Gaojiao-ro, Hangzhou 31122, People’s Republic of China; Zhejiang Engineering Research Center on Smart Rail Transportation, 201 Gaojiao-ro, Hangzhou 31122, People's Republic of China.

J.-T. Han and S. Kim. Korea Institute of Civil Engineering and Building Technology, 283 Goyangdae-ro, Ilsanseo-gu, Goyang 10223, Republic of Korea.

Corresponding author: Jin-Tae Han (email: jimmyhan@kict.re.kr).

() 2021 The Author(s). This work is licensed under a Creative Commons Attribution 4.0 International License (CC BY 4.0), which permits unrestricted use, distribution, and reproduction in any medium, provided the original author(s) and source are credited. 
Fig. 1. Concept of waveform micropile construction (Jang and Han 2018).
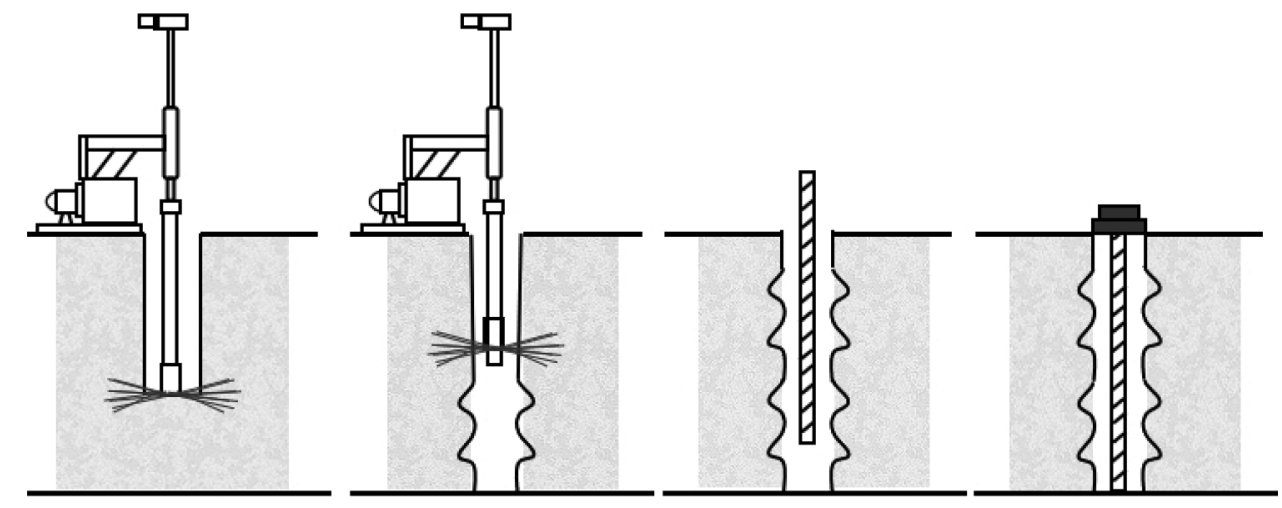

Fig. 2. Plan view of micropile locations (MP and WMP), boreholes (BHs), cone penetration test (CPT), standard penetration tests (SPTs), instrumentation (dimensions are in millimetres and are not to scale). [Color online.]

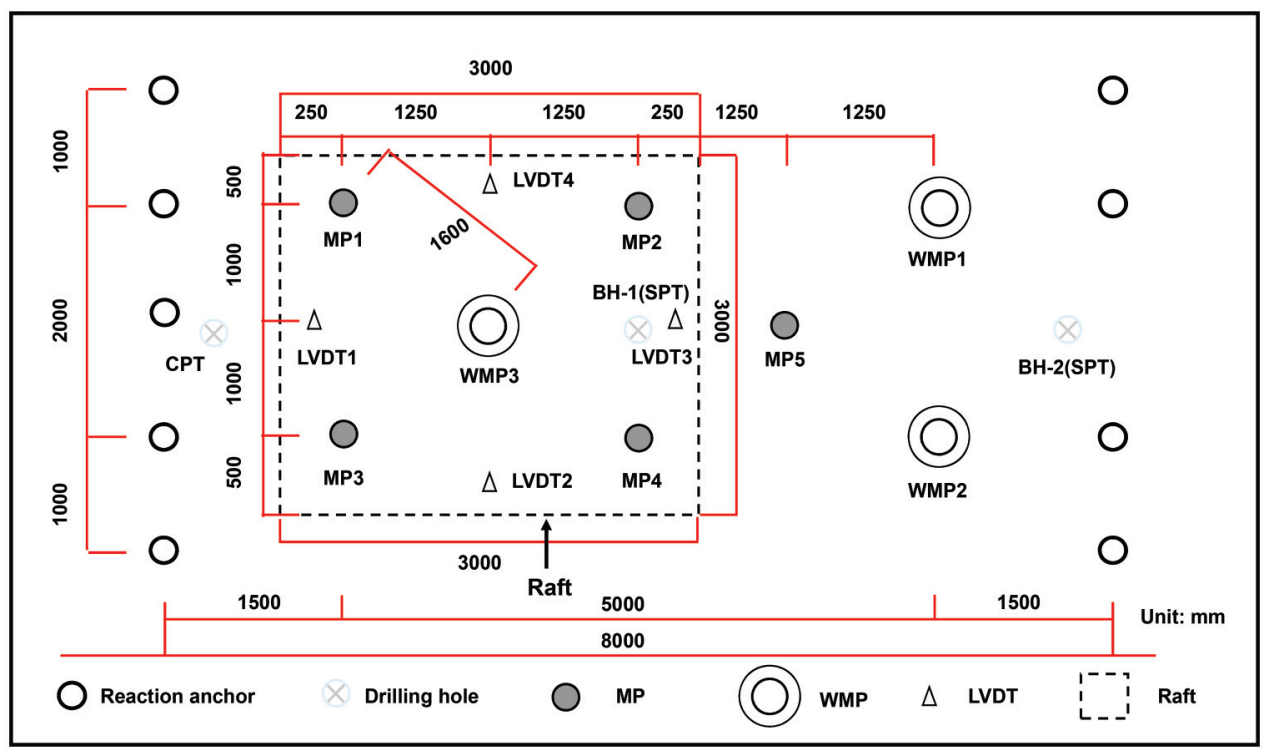

on the load sharing of micropile than its elastic modulus. Tsukada et al. (2006) performed a series of small-scale tests to evaluate the reinforcing performance of micropiles in a spread footing. They reported that the bearing capacity of the foundation reinforced with micropiles increased significantly in dense sand. However, the load transfer mechanism between existing piles and micropiles is yet to be appropriately investigated or understood.

A waveform micropile (WMP) is a novel type of micropile that uses jet-grouting method for drilling and grouting holes simultaneously in a single-step process, similar to the construction sequence of hollow bar micropiles. In addition, the WMP does not require casings during drilling, and therefore, can facilitate a faster installation process and cost effectiveness (Drbe and El Naggar 2015; Abdlrahem and El Naggar 2020). During its construction, jet-grouting methods are used to develop shear keys along the pile shafts by controlling the grouting pressure and ascent time (Jang and Han 2018). Figure 1 depicts the construction process of an instrumented WMP: (i) drilling a hole through a water jet; (ii) waveform grout formation by controlling grouting pressure and time; (iii) inserting reinforcing steel bar; (iv) grout curing for a month. Generally, WMPs are constructed based on soil types such as sandy and gravelly soil owing to the applicability of the jet-grouting method (Peplow et al. 1999). In context, Jang and Han (2018) verified the field constructability of WMPs and reported that the bearing capacities of such micropiles were 1.4-2.3 times higher than those of type A micropiles (MP). Moreover, WMPs have been developed to improve both the bearing capacity and economic efficiency of MPs by enhancing the shaft resistance in the upper soil layers (Jang and Han 2018, 2019). Furthermore, the superior underpinning performance of WMPs has been confirmed using numerical analysis in comparison with type A MPs (Wang et al. 2018). However, the underpinning performance of a WMP is yet to be investigated based on field experiments.

The underpinning performance in terms of load sharing capacity of a pile in a pile group is affected by its axial stiffness (Randolph 1983; Poulos 2001; Fleming et al. 2009). Therefore, the axial stiffnesses of existing piles and underpinning piles are essential factors for determining the load sharing behavior between existing piles and MPs in underpinned foundations (Makarchian and Poulos 1996, Leung et al. 2011; Kim et al. 2019; Wang et al. 2019a, 2019b; Jeong and Kim 2020). Based on small-scale experiments, Wang et al. (2019b) found that the load sharing capacity of a pile increased with its stiffness capacity. Thus, they proposed a relationship between the load sharing characteristics of the pile and the stiffness ratio of an existing pile placed over an underpinning pile. However, they did not consider the influence of the soil confining stress. Kim et al. (2019) estimated the axial stiffness of an underpinning pile and its 
influence on the load carrying capacity via numerical analysis. Jeong and Kim (2020) proposed an axial stiffness range to achieve an optimal underpinning design, considering the deterioration of the existing piles.

In this study, the underpinning performance of a WMP was investigated in a $2 \times 2$ micropiled raft. Thus, we primarily focused on the evaluation of $(i)$ the axial performance of a single WMP compared with a type A MP under compressive loading and (ii) the underpinning performance of a WMP in a micropiled raft. For achieving the first objective, three WMPs and five type A MPs were subjected to compressive load for evaluating the axial performances in terms of bearing capacity, load transfer behavior, and axial stiffness. For fulfilling the second objective, four type A MPs were employed to represent the existing piles. In addition, a single WMP installed in the center of four type A MPs was adopted to act as the underpinning pile, and a raft was cast on the pile group to represent an underpinned foundation. Furthermore, a loading test was performed on the micropiled raft to evaluate the influences of the axial stiffnesses of the MPs on the short- and long-term load sharing characteristics of the type A MPs, WMP, and raft.

\section{Experimental setup}

\section{Site conditions}

Field loading tests were performed in Icheon, South Korea. Figure 2 presents a plan view of the test site, including the location of the in situ testing along with that of the MPs. Two standard penetration tests (SPTs) were conducted as depicted in Fig. 3. The boreholes uncovered the uppermost layer of the site soil that was formed by a $3.8 \mathrm{~m}$ fill layer of loose-to-medium density sand, below which a deposit of silty clay mixed with sand reached a depth of $5.4 \mathrm{~m}$, followed by a weathered soil layer of medium-to-dense silty sand. The SPT $N$ value indicated that the soil was highly dense downward from the weathered soil layer. The deepest bearing stratum was located at depths from 12 to $18 \mathrm{~m}$ and comprised weathered rock.

Moreover, two piezocone penetration test (CPTU) were performed at the site, as illustrated in Fig. 4. The average cone tip resistance ranged from 500 to $1500 \mathrm{kPa}$ at depths of $2-5 \mathrm{~m}$ in the upper soil. In addition, the undrained shear strength ranged from 30 to $60 \mathrm{kPa}$. Based on the results of CPTU tests, the method proposed by Roberston et al. (1986) was used for the soil classification as shown in Fig. 5. It is shown that numerous silt and sand were mixed in the clayey soil layer. Moreover, two borehole shear tests of BH-2 at depths of 7.7 and $8.5 \mathrm{~m}$ were conducted to measure the vertical stress and shear stress of weathered soil and weathered rock, respectively. Therefore, cohesion and internal frictional angle were obtained by linear regression method. The results of borehole shear tests are presented in Fig. 6, which displays that the cohesion and internal frictional angle of the weathered soil at a depth of $7.7 \mathrm{~m}$ was $26.62 \mathrm{kPa}$ and $27.29^{\circ}$, respectively. The cohesion and internal frictional angle of the weathered rock at a depth of $8.5 \mathrm{~m}$ was $34.89 \mathrm{kPa}$ and $38.2^{\circ}$, respectively.

\section{Installation of micropiles}

Five type A MPs and three WMPs were constructed and subjected to compressive loading. Schematics of the type A MPs and WMPs are shown in Fig. 7. According to the Federal Highway Administration (FHWA) classification (FHWA 2005), the studied type A MPs were constructed by drilling a borehole, placing a casing in the upper soil layers, placing a steel reinforcement in the casing, and grouting the hole. The dimensions of type A MPs are presented in Table 1, wherein each type A MP had a steel casing with an outer diameter of $200 \mathrm{~mm}$. The permanent casings were installed in the weak soil layers. However, as depicted in Fig. 3, the casings lengths of MPs varied with the depths of the weak soil layer owing to the varying ground conditions in the field. In addition, the casing lengths of MPs were measured after construction, as listed in Table 1. The total length of MP1-MP4 were $15.7 \mathrm{~m}$, and
Fig. 3. Soil profile and SPT value: (a) borehole-1 (BH-1); (b) borehole-2 (BH-2).
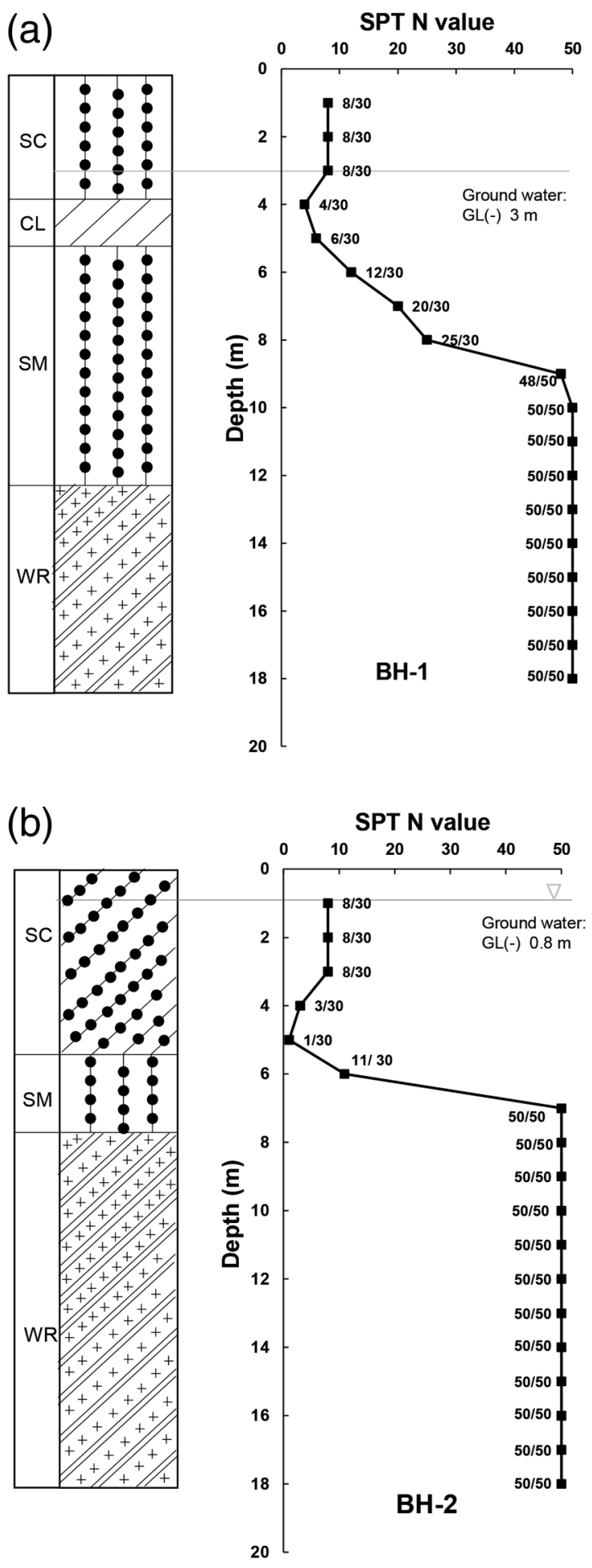

the length of MP5 was $15.7 \mathrm{~m}$ for comparing the influence of pile length on its axial stiffness.

In contrast, the WMPs were constructed using the jet-grouting method, without the installation of casings. Based on the ground conditions, three WMPs were installed in the weathered soil layer with a length of $10.9 \mathrm{~m}$. Following the installation method of the WMP (Jang and Han 2018), the double-tube jet-grouting method was applied in the test. The grout was prepared using a 

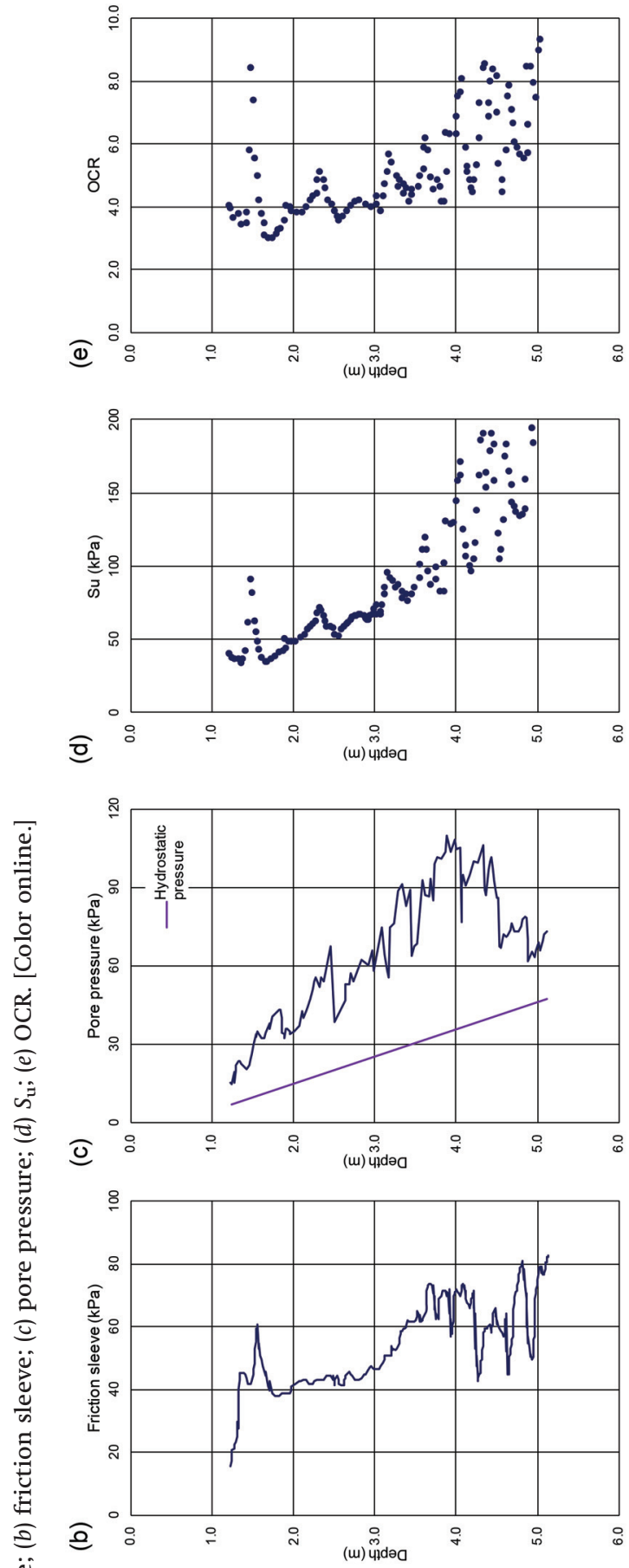

Fig. 6. Borehole shear test at depths of 7.7 and $8.5 \mathrm{~m}$ for weathered soil (WS) and weathered rock (WR), respectively. [Color online.]

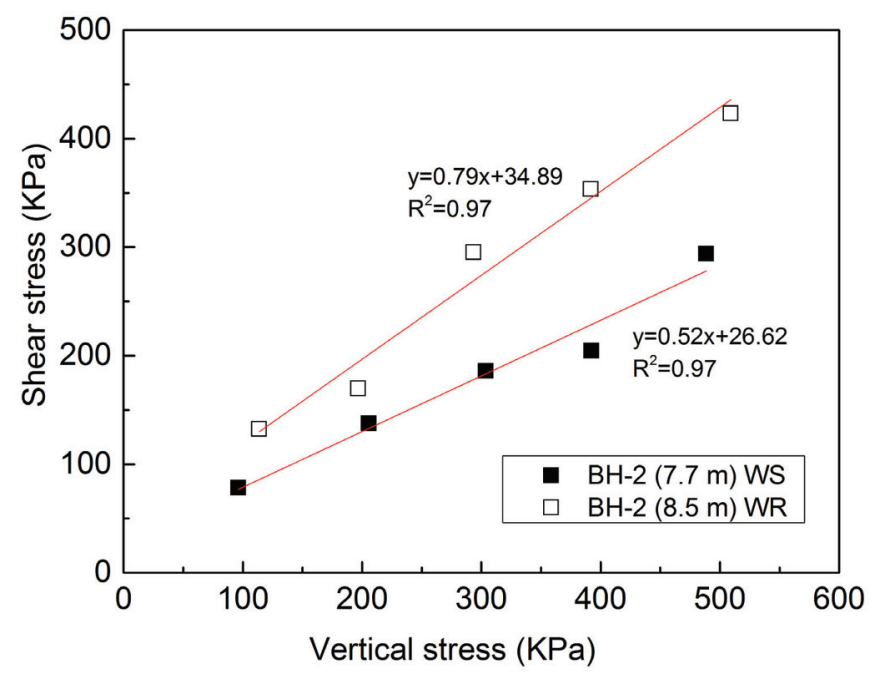

mixture of water and cement with a ratio of 0.8 . The grouting pressure was controlled at 400 bar with an ascent velocity of $5 \mathrm{~s} / \mathrm{cm}$ and $3 \mathrm{~s} / \mathrm{cm}$ for forming the shear key diameter $\left(D_{2}\right.$ in Fig. 7) of $500 \mathrm{~mm}$ and body diameter $\left(\mathrm{D}_{1}\right.$ in Fig. 7) of $300 \mathrm{~mm}$, respectively.

Test setup, methods, and instrumentation

As shown in Fig. 2, the center-to-center spacing between WMP and each type A MP was more than 3 times the diameter of MP, which is a prevalent MP spacing (Bruce et al. 2005; Abdlrahem and El Naggar 2020; FHWA 2005). The loading test setup included a reaction beam, two tension anchors acting as reaction supports, a hydraulic jack, and two displacement gauges. According to the criterion of the American Society for Testing and Materials (ASTM) D1143 standard (ASTM International 2013), quick loading tests were performed on the studied MPs. The test load was applied in increments of $40 \mathrm{kN}$, and each load increment was maintained for $10 \mathrm{~min}$. In the loading tests for single MPs, a total load of up to 
Fig. 7. Schematic of conventional and waveform micropile. $L$, vertical length of a sectional shear key; $S$, length of a sectional main body. [Color online.]
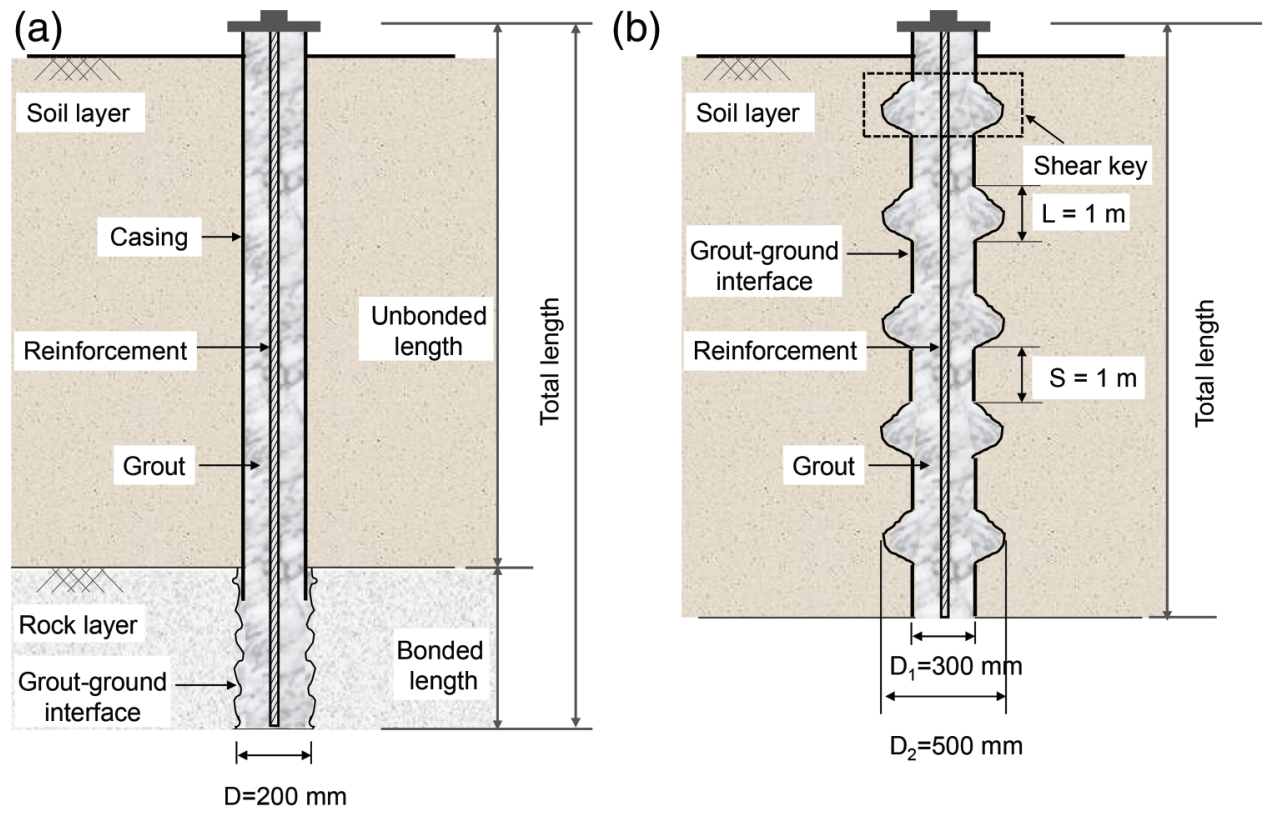

Table 1. Dimensions of test micropiles.

\begin{tabular}{lllllll}
\hline No. & $\begin{array}{l}\text { Total length } \\
(\mathrm{m})\end{array}$ & Diameter $(\mathrm{mm})$ & $\begin{array}{l}\text { Slenderness } \\
\text { ratio }\end{array}$ & $\begin{array}{l}\text { Bonded } \\
\text { length }(\mathrm{m})\end{array}$ & $\begin{array}{l}\text { Cased length } \\
(\mathrm{m})\end{array}$ & $\begin{array}{l}\text { Diameter of } \\
\text { steel bar }(\mathrm{mm})\end{array}$ \\
\hline CMP1 & 15.7 & 200 & 78.5 & 9.7 & 6 & 50 \\
CMP2 & 15.7 & 200 & 78.5 & 6.7 & 9 & 50 \\
CMP3 & 15.7 & 200 & 78.5 & 3.7 & 12 & 50 \\
CMP4 & 15.7 & 200 & 78.5 & 6.7 & 9 & 50 \\
CMP5 & 18 & 200 & 90 & 9 & 9 & 50 \\
WMP1 & 10.9 & $D_{1}: 300 ; D_{2}: 500$ & 36.3 & 10.9 & - & 50 \\
WMP2 & 10.9 & $D_{1}: 300 ; D_{2}: 500$ & 36.3 & 10.9 & - & 50 \\
WMP3 & 10.9 & $D_{1}: 300 ; D_{2}: 500$ & 36.3 & 10.9 & - & 50 \\
\hline
\end{tabular}

Note: $D_{1}$, diameter of pile shaft; $D_{2}$, diameter of the shear key.

2 times the design load $-400 \mathrm{kN}$ (considered 0.5 times the predicted allowable bearing capacity with a safety factor of 2), corresponding to the pile foundation design criterion under South Korean standard (Cho 2010; KHS 2008), was applied to MP1, MP2, MP3, MP4, and WMP3 because these MPs were used for the micropiled-raft loading test, subsequently; conversely, for MP5, WMP1, and WMP2, the applied load was increased until pile failure. Two linear variable differential transformers (LVDTs) were installed to measure the settlement on the head of MPs. In addition, MP1 and MP5 had five pairs of strain gauges (TML-FLAB-5-11) placed at 0.8, $3.8,5.4,12$, and $15.6 \mathrm{~m}$ from the ground surface. WMP1 and WMP3 had three pairs of strain gauges (TML-FLAB-5-11) placed at 0.8, 3.8, 5.4 , and $10.9 \mathrm{~m}$ from the ground surface.

The grout was cured for 30 days after the installation of the test MPs. Prior to the loading test, the functionality of all the gauges were confirmed, and they were subsequently connected to a data logger displaying the resistance values of the strain gauges balanced to $0 \pm 3 \mu \mathrm{s}$. It must be stated that the strain gauges attached to MP5 were partly damaged during the test. As a result, only the data associated with MP1 and WMP3 will be used in this study for the purpose of comparing load transfer behavior between MP and WMP. As shown in Fig. 8, to keep the survivability of strain gauges during loading, waterproof coating was applied to each strain gauge and then a protective cover was installed to envelop the strain gauge. Upon conducting the single-pile loading tests, a raft with a width, length, and height of $3 \mathrm{~m}, 3 \mathrm{~m}$, and $0.8 \mathrm{~m}$, respectively, was cast with concrete on the heads of MP1, MP2, MP3, MP4, and WMP3, as illustrated in Fig. 9. After concrete curing for one month, a loading test was performed on the piled raft to evaluate the MP underpinning performance in terms of the load sharing capacity. Before applying loads, zero calibration was performed on all strain gauges, because, in this study, instead of the absolute strain value, what matters is the delta value, i.e., the augment of strain value as per each reloading. Four LVDTs were used to measure the settlement on the micropiled raft, and strain gauges attached to the head of MPs were used to measure the carried load when subjected to vertical load to the micropiled raft. In the micropiled raft, the type A MPs represented existing piles and the WMP acted as the underpinning pile. The long-term load transfer behavior among the type A MPs, WMP, and raft was investigated for two months.

\section{Analysis of test results}

\section{Single-pile loading test}

\section{Load-settlement behavior of MPs}

Figure 10 presents the load-settlement responses of the eight individual MPs subjected to compression. It should be noted that only WMP1, WMP2, and MP5 were loaded up to the failure state; the other MPs were loaded up to 2 times the design load $(400 \mathrm{kN})$. The variation in the load-settlement behavior of type A MPs was 
Fig. 8. Installation of strain gauges: (a) attachment of strain gauge; (b) protective cover on the strain gauge. [Color online.]

(a)

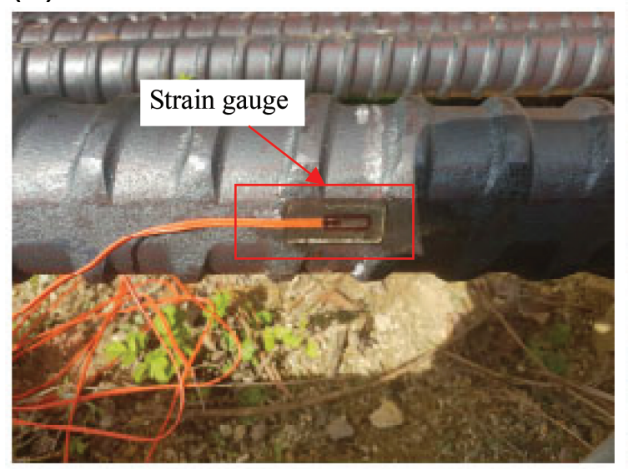

(b)

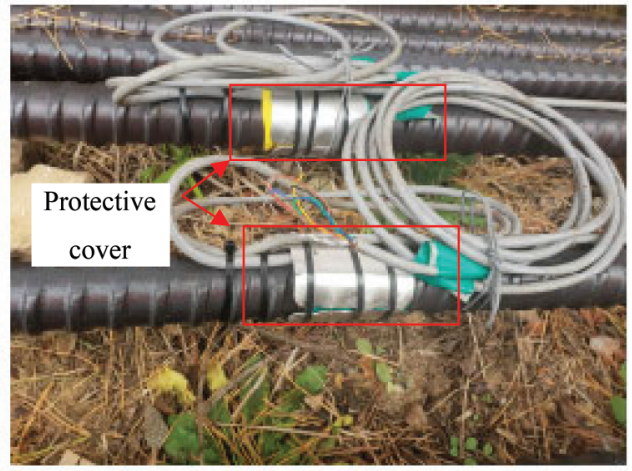

Fig. 9. Loading test of the micropiled raft. [Color online.]

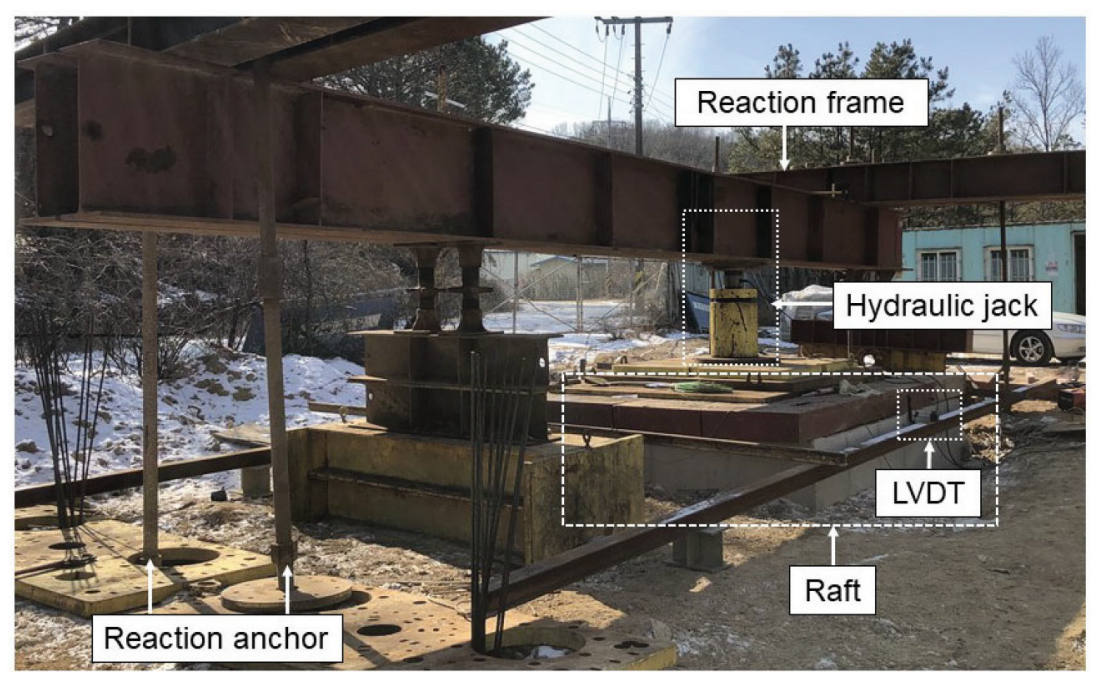

attributed to the various bonded lengths listed in Table 1 . The bearing capacity increased with increasing bonded length of a MP. The load-settlement curve for WMPs exhibit a plunging failure at $1670 \mathrm{kN}$ corresponding to the settlement of $23 \mathrm{~mm}$, which was less than $10 \%$ of the WMP diameter $(300 \mathrm{~mm})$, thereby indicating that most of the applied load was transferred through the WMP shaft. However, based on the aforementioned criterion, MP5 reached a bearing capacity of $1700 \mathrm{kN}$ at a settlement of $38 \mathrm{~mm}$, which is $19 \%$ of the MP diameter. Therefore, from a conservative point view, the bearing capacity of MP5 was estimated as $1100 \mathrm{kN}$, according to the failure criterion in which the failure load corresponds to the load at a settlement of $10 \%$ of the MP diameter. The bearing capacities of the WMPs are $50 \%$ higher than those of the type A MPs, even with a $40 \%$ shorter length.

\section{Load transfer behavior in single piles}

Figure 11 shows the load distribution profiles corresponding to each loading step for a type A micropile (MP1) and a WMP (WMP3). Figure 11a shows that although there was some resistance mobilized in the upper layer, almost all the shaft capacity of MP1 was the result of the shaft resistances provided by the weathered soil and rock. This is attributed to the installation of the casing and the relatively low strength of the upper soil layer. Conversely, the shaft resistance of WMP3 was highly mobilized in the upper layer (Fig. 11b), which is attributed to the shaft resistance strengthening effect of the shear keys (Jang and Han 2018). Compared with the type A micropile, the increase in the shaft resistance of WMP3, even in the loose soil layer, indicates that the shear keys of WMPs not only increase the resisting area, but also densify the ground owing to the large compressive stress transmitted to the surrounding soils during shear key formation via jet grouting. Moreover, the soil densification improved the surrounding soil strength owing to the pressurized grout, which has been also reported in published literatures (Bergado and Lorenzo 2003; Shibazaki 2003; Shen et al. 2013; Jang and Han 2018).

Figure 12 shows the proportion of shaft and tip resistance mobilized in MP1 and WMP3 as a function of the applied load and the settlement normalized to the pile diameter $(s / D)$. The load $Q_{\mathrm{b}}$ transferred to the pile base was estimated using data from the strain gauges located at the pile base. Figure $12 a$ shows that before the head of MP1 settled by approximately $1 \%$ of the MP diameter, no load had been transferred to the pile base. At the final loading level, $13 \%$ of the applied load was transferred to the base of MP1. In contrast, for WMP3 (Fig. 12b), even at a maximum applied load of $800 \mathrm{kN}$ (allowable bearing capacity with a safety factor of 2), the pile head settled by $2 \%$ of the MP diameter, and the load was rarely transferred to the base. This indicates that the WMP resists most of the load from the shaft resistance and transfers less load to the tip of the pile. Moreover, the settlement is decreased by the shaft resistance, compared with the type A MPs.

The shaft load mobilized per unit area of MP1 and WMP3 with respect to the soil depth is presented in Fig. 13. For MP1, as shown in Fig. 13a, owing to the installation of the casing in the upper soil layer from 0 to $6 \mathrm{~m}$, the shaft resistance mobilizes in the weathered soil and weathered rock layers. In addition, the skin 
Fig. 10. Single-pile loading tests of micropiles.

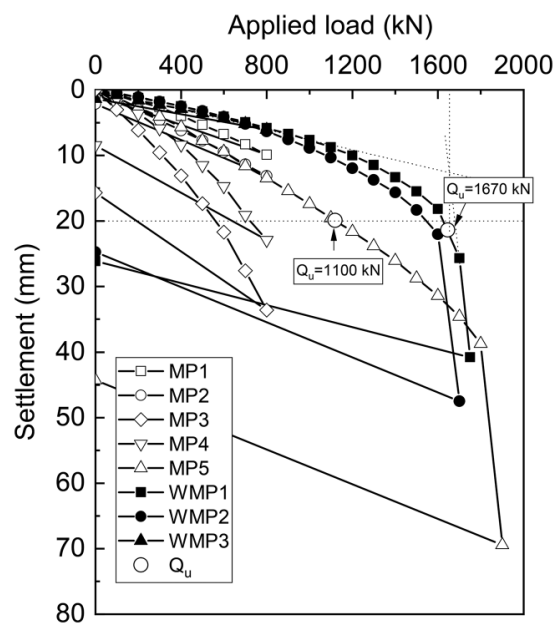

friction of MP1, which is approximately 2 times that of WMP3 in the same layer, increases sharply. For WMP3, as shown in Fig. 13b, at loose soil depths from 0 to $4 \mathrm{~m}$, the mobilization of the shaft resistance is higher than that at greater depths, and the shaft resistance reaches $130 \mathrm{kN} / \mathrm{m}^{2}$ at the final loading level of $800 \mathrm{kN}$. At depths from 4 to $6 \mathrm{~m}$, the mobilization of the shaft resistance for WMP3 is lower than that for MP1 in the upper soil layer because the soil strength is significantly low and the number of shear keys is less than that at depths from 0 to $4 \mathrm{~m}$. In the deep soil layer from 6 to $11 \mathrm{~m}$, the shaft resistance of WMP3 is $80 \mathrm{kN}$ at the final loading level, which is 0.6 times that in the upper soil layer from 0 to $4 \mathrm{~m}$, which reveals that the shaft resistance increased in the vicinity of shear key location. These results indicate that WMPs resist vertical loads mainly through the shaft resistance at shallow ground, while type A MPs resist loads through the shaft resistance and tip resistance at deep ground layers with high soil strength.

\section{Axial stiffness of the MPs}

Figure 14 presents the MP secant stiffness, which is defined as the load applied at the pile head divided by the pile settlement, as a function of the applied load. The stiffness variation among type A MPs with identical dimensions is caused by slight differences in the ground characteristics and the different bonded lengths. The MPs generally present their highest stiffness at the outset; however, by increasing the load on the MP head, the MP stiffness decreases and becomes almost constant for applied loads between 200 and $800 \mathrm{kN}$. For type A MPs (MP2-MP5) embedded in rock, with increasing the applied load above $200 \mathrm{kN}$, the stiffness rarely decreases. In contrast, the stiffnesses of the WMPs (WMP1-WMP3) installed in the soil layer decrease progressively with increasing the load. This is owing to the higher nonlinear stress-strain behavior of soil than that of rock. Similarly, for MP1, the longer bonded length in soil layer compared with other MPs probably lead to a slight reduction of the stiffness with applied load. The stiffness of a WMP ranges from 130 to $160 \mathrm{kN} / \mathrm{mm}$ at the design load, which is $2-5$ times that of a type A MP, which ranges from 30 to $100 \mathrm{kN} / \mathrm{mm}$. The increasing axial stiffness in WMPs was probably attributed to the generation of the shear keys and the strength enhancement of the soil surrounding the pile shaft through the jet-grouting method.

The axial stiffness of a single pile depends on the pile material stiffness and the pile-soil interaction, which is defined as the slope of the load-settlement curve and can be obtained from singlepile loading tests. Table 2 presents the MP material stiffness for the case of no pile-soil interaction, the initial MP axial stiffness, and the
Fig. 11. Axial load distributions in micropiles under axial loading: (a) MP1; (b) WMP3.
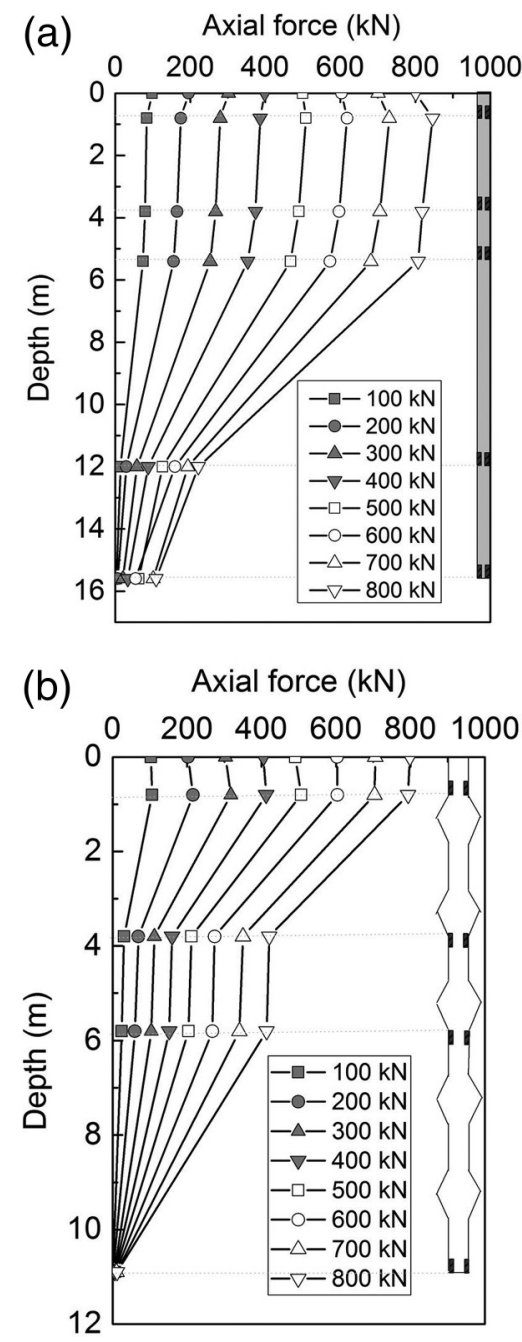

MP axial stiffness at the design load level. The material stiffness of a MP, $k$, is calculated as

(1) $\quad k=\frac{E_{\mathrm{p}} A_{\mathrm{p}}}{L_{\mathrm{p}}}$

where $E_{\mathrm{p}}$ denotes the Young's modulus of the pile (MPa), $A_{\mathrm{p}}$ represents the pile sectional area $\left(\mathrm{m}^{2}\right)$, and $L_{\mathrm{p}}$ is the pile length $(\mathrm{m})$. The Young's modulus of a micropile under compression can be backcalculated from the measured strains near the pile heads and the applied loads as follows (Han and Ye 2006):

(2) $\sigma_{\mathrm{p}}=\frac{P_{\mathrm{p}}}{A_{\mathrm{p}}}$
(3) $\mathrm{E}=\frac{\sigma_{\mathrm{p}}}{\varepsilon}$

where $P_{\mathrm{p}}$ is the load applied on the MP head, $\sigma_{\mathrm{p}}$ is the average stress on the pile section, and $\varepsilon$ is the strain in the steel reinforcement. The average stresses along the MP section for the measured strain values are plotted in Fig. 15. It can be clearly observed that the Young's modulus of the MP is the slope of the corresponding line in Fig. 13; therefore, the Young's modulus of a type A MP is approximately $20-30$ GPa and that of a WMP is $10 \mathrm{GPa}$. 
Fig. 12. Proportion of tip and shaft resistance of micropile under vertical loading: (a) MP1; (b) WMP3.

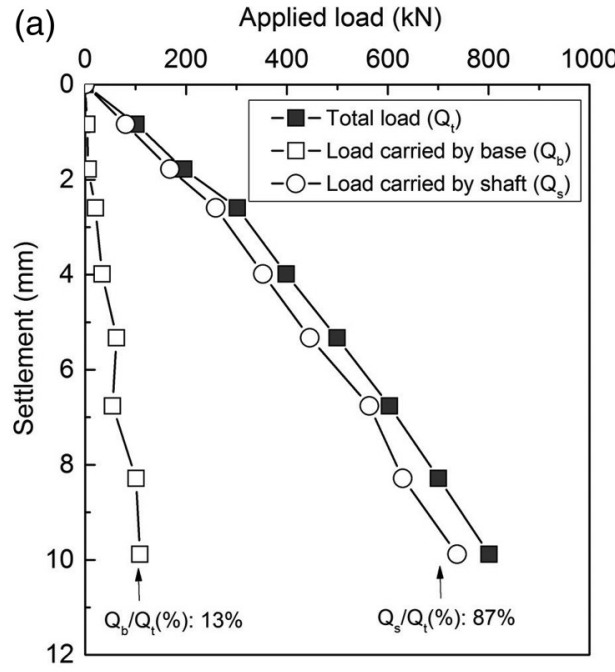

(b)

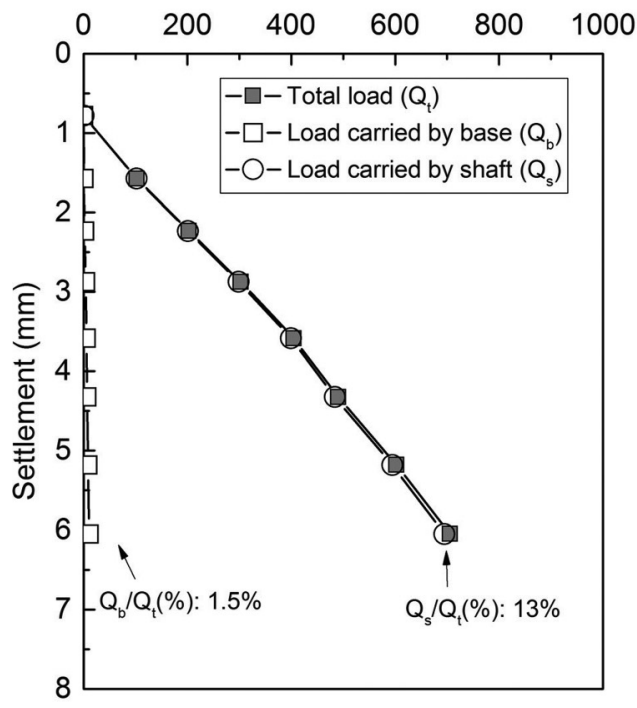

The axial stiffness, $k_{v}$, of a MP can be defined as

$$
\text { (4) } \quad k_{\mathrm{v}}=\alpha k
$$

where $\alpha$ is the stiffness coefficient, which is related to the pilesoil interaction, construction method, and grout pressure.

As shown in Table 2, an increase in the MP slenderness ratio reduced the MP material stiffness; the shorter bonded length of MP3 leads to a lower axial stiffness than those of the other MPs. With the exception of MP3, the stiffness coefficient $\alpha$ is larger than 1, which indicates that for both type A and WMPs subjected to compression, the pile-soil interaction increases the axial stiffness. This implies that the installation of MPs using the grouting method strengthens the adhesion of the pile-soil interface. The $\alpha$ value of a WMP is 1.2-2 times that of a type A micropile. This is attributed to the shear keys generated by the jet-grouting method, which increase the partial cross-sectional area and densify the surrounding soil, as reported by Jang and Han (2018).

Based on the above results, it is observed that the micropile axial stiffness is highly dependent on the material stiffness,
Fig. 13. Shaft load per unit area along micropiles under axial loading: (a) MP1; (b) WMP3.

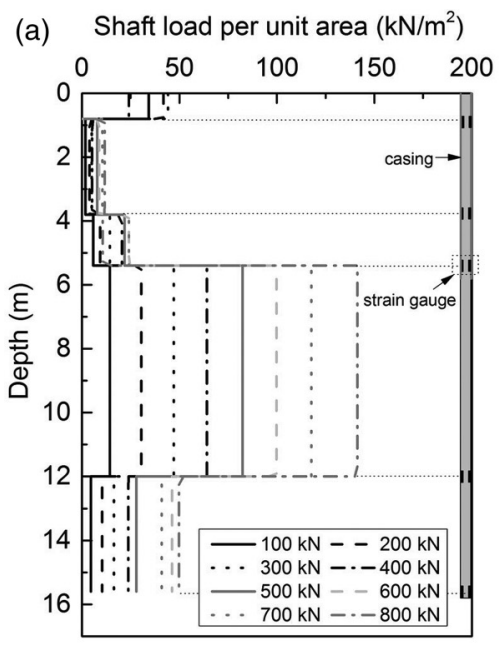

(b) Shaft load per unit area $\left(\mathrm{kN} / \mathrm{m}^{2}\right)$

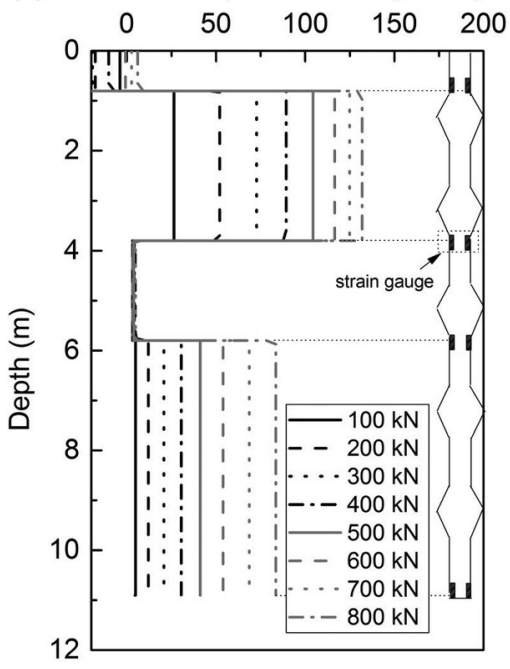

slenderness ratio, and pile-soil interaction. By comparison between MP1 and WMP3 at the design load, the axial stiffness of WMP3 is $30 \%$ higher than that of MP1 because the former presents a $20 \%$ higher material stiffness and a $10 \%$ higher pilesoil interaction that the latter. Compared with MP1, which has a longer bonded length in the rock layer, the higher pile-soil interaction of WMP3 implies that the axial stiffness of WMPs is highly affected by the pile-soil interface stiffness and the soil strength in the upper ground layer. The shear keys generated along the WMP improve the pile-soil interaction and the stiffness of the pile-soil interface; the construction of such keys through the jetgrouting method, which has been demonstrated to be an effective ground improvement technique (Han et al. 2007; Ho 2007; Ni and Cheng 2012), also improves the soil strength. These factors contribute to the higher axial stiffnesses of WMPs compared with that of type A MPs.

\section{Micropiled-raft loading test}

The configuration of the investigated micropiled raft is shown in Fig. 7; a load of $2000 \mathrm{kN}$ with the increment of $250 \mathrm{kN}$ was applied on the raft. A group pile loading test was performed to evaluate the effect of the WMP stiffness on the micropile underpinning performance. In this test, the type A MPs represented existing piles and the WMP acted as the underpinning pile. 
Fig. 14. Variation of micropile stiffness with applied loads.

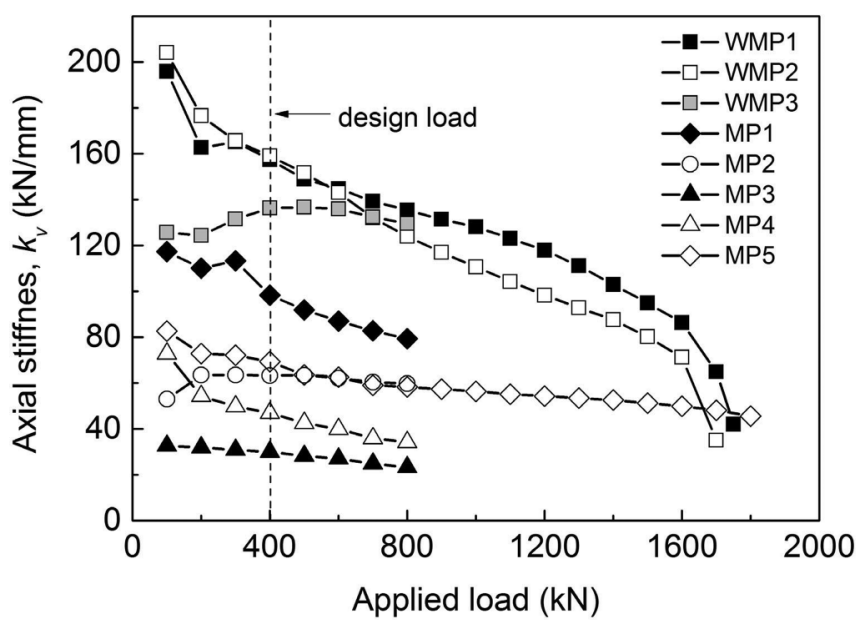

Load-settlement behavior of micropiled raft

Figure 16 presents the load-settlement behavior of the micropiled raft. The settlement values measured by the LVDTs display similar behaviors, except for those measured by LVDT1. It is considered that this is because LVDT1 was installed near MP3, which presents the lowest stiffness and bearing capacity. The micropiled raft does not reach the failure state under the applied load, and the average settlement at the final load $(2000 \mathrm{kN})$ is $4 \mathrm{~mm}$. At an initial loading level below $400 \mathrm{kN}$, the load-settlement response exhibits a linear behavior, and the axial stiffness of the piled raft, obtained as the slope of the load-settlement curve at the initial load level, is $800 \mathrm{kN} / \mathrm{mm}$.

\section{Load sharing ratio of micropiled raft}

The axial load supported by the MPs and the raft in a micropiledraft foundation is affected by the raft flexibility, the stiffnesses of the piles, and the direct contact between the raft and the subsoil (Cao et al. 2004; Lee and Chung 2005; El Sawwaf 2010; El Garhy et al. 2013; Wang et al. 2018). Figure 17 presents the curves of the supported load and load sharing ratio of the piles and the raft. In the early stage of loading, the load sharing ratio of the raft (43\%) is larger than those of the piles. This differs from the findings of previous studies (Alnuaim et al. 2015), which reported that the MPs supported higher loads than the raft because of the lack of intimate contact between the raft and the clay. The results presented herein demonstrate that the raft was in good contact with the subsoil. With increasing total load, the load shared by the raft increases slowly, while the load sharing ratio of the raft decreases gradually. Based on the results of CPT tests, the strength of subsoil at depths of 1-4 m ranged from 50 to $100 \mathrm{kPa}$. Assuming a uniform load was applied to the raft, the stress on the raft was evaluated as $67 \mathrm{kPa}$, which potentially exceeded the soil strength. This implied that the upper layer of the loose soil below the raft yielded, and the load was transferred to the piles. When the load increases to the final load, the load sharing ratio of the raft decreases to $29 \%$. A minute variation in the load sharing ratio is observed for the type A MPs with applied loads, while the load sharing ratio of the WMP increases from $19 \%$ to $26 \%$ with the increasing load; the load sharing ratio of the WMP is 2-3 times that of a type A MP, depending on the stiffness. It is noted that residual settlement was induced during the single-pile loading tests (see Fig. 10). The residual settlements of MP3 and MP4 (15.7 and $8.5 \mathrm{~mm}$, respectively) were observed to exceed the elastic zone of the load-settlement curve, which results in reduced stiffness and therefore lower load sharing compared with MP1 and MP2.
Horikoshi and Randolph (1998) proposed a simplified method for estimating the overall stiffness of a piled raft, based on the singlepiled raft stiffness estimation approach proposed by Randolph (1983). In this approach, the group pile filled with soil is considered an equivalent pier, and the overall stiffness, $k_{\mathrm{pr}}$, is given as follows:

$$
k_{\mathrm{pr}}=\frac{P_{\mathrm{p}}+P_{\mathrm{r}}}{S_{\mathrm{pr}}}=\frac{k_{\mathrm{pi}}+k_{\mathrm{r}}\left(1-\alpha_{\mathrm{rp}}\right)}{1-\left(k_{\mathrm{r}} / k_{\mathrm{pi}}\right) \alpha_{\mathrm{rp}}^{2}}
$$

where $P_{\mathrm{p}}$ is the load supported by the piles, $P_{\mathrm{r}}$ is the load supported by the raft, $S_{\mathrm{pr}}$ is the average settlement of the piled raft, $k_{\mathrm{pi}}$ is the stiffness of the equivalent pier, $k_{\mathrm{r}}$ is the stiffness of the raft, and $\alpha_{\mathrm{rp}}$ is the interaction factor; $\alpha_{\mathrm{rp}}$ can be calculated as follows:

$$
\alpha_{\mathrm{rp}}=1-\frac{\ln \left(r_{\mathrm{r}} / r_{\mathrm{pi}}\right)}{\ln \left(r_{\mathrm{m}} / r_{\mathrm{pi}}\right)}
$$

where $r_{\mathrm{r}}$ is the radius of the raft, $r_{\mathrm{r}}=\sqrt{\mathrm{BL} / \pi}$ for rectangular rafts (where $B$ is the breadth of the raft and $L$ is the length of the raft), $r_{\mathrm{pi}}$ is the radius of the pier converted from the square pier area containing the MPs filled with soil (Han and Ye 2006), and $r_{\mathrm{m}}$ is the maximum radius of influence of the equivalent pier. $r_{\mathrm{m}}=$ $2.5 \rho(1-v) / L_{\mathrm{p}}$, where $L_{\mathrm{p}}$ is the pile length and $\rho$ is the ratio of average shear modulus to shear modulus at a depth equal to the pile length ( $\rho=1$ and $L_{\mathrm{p}}=15.7 \mathrm{~m}$ were used in this study).

The stiffnesses of the MPs and the piled raft were obtained from the loading tests (Figs. 10 and 14). Based on eq. 5, the stiffness of the raft was back-calculated as $428 \mathrm{kN} / \mathrm{mm}$. The proportion of total applied load supported by the raft $\left(\mathrm{LSR}_{\mathrm{r}}\right)$ in a piled raft system can be determined using the stiffness of each foundation element as follows (Horikoshi and Randolph 1998):

$$
\mathrm{LSR}_{\mathrm{r}}=\frac{\mathrm{P}_{\mathrm{r}}}{P_{\mathrm{t}}}=\frac{k_{\mathrm{r}}\left(1-\alpha_{\mathrm{rp}}\right)}{k_{\mathrm{p}}+k_{\mathrm{r}}\left(1-2 \alpha_{\mathrm{rp}}\right)}
$$

where $P_{t}$ is the total applied load on the piled raft.

Based on the measured and calculated stiffness values for the MPs and the raft, the load sharing ratio of the raft was calculated as $33 \%$, which is $3 \%$ lower than the average measured value $(29 \%-$ $43 \%)$. That is, the experimental result is in good agreement with the theoretical result.

In Fig. 18, the shaft resistance along WMP3 and MP1 in the single-pile loading test is compared with that along the same MPs in the micropiled-raft loading test. The shaft resistance distributions along the MPs during the pile-group and single-pile loading tests present similar tendencies. Moreover, the results show that the shaft resistance mobilized near the pile head in the singlepile loading test is higher than that in the group-pile loading test. Based on the experimental results recorded by Han and Ye (2006), the reduction of shaft resistance in the vicinity of the MP heads in the group-pile loading test resulted from the stress applied by the raft on the subsoil, which minimized the mobilization of the shaft resistance. In contrast, at depths greater than $6 \mathrm{~m}$, the MP shaft resistance mobilization in the single-pile loading test was lower than that in the pile-group loading test, because the stress did not pose a significant influence on the soil after a certain depth. Comparison of unit shaft resistance between WMP3 and MP1 as shown in Figs. 18a and 18c, the effect of shear keys increased the unit shaft resistance in the loose soil layer $(0-4 \mathrm{~m})$, which is 4 times greater than that of MP1. In contrast, the effect disappeared in the dense soil layer $(6-11 \mathrm{~m})$. This indicates that the effect of shear keys on increasing unit shaft resistance in loose soil is more significant.

\section{Long-term load sharing behavior of micropiled raft}

The micropiled raft was monitored for two months (from 11 February to 19 April 2020). The load sharing ratios of the MPs and 
Table 2. Comparison of material stiffness and axial stiffness at different loading level of a micropile.

\begin{tabular}{llllcl}
\hline Pile & $\begin{array}{l}\text { Slenderness } \\
\text { ratio }\end{array}$ & $\begin{array}{l}\text { Material stiffness } \\
(\mathrm{kN} / \mathrm{mm})\end{array}$ & $\begin{array}{l}\text { Initial stiffness } \\
(\mathrm{kN} / \mathrm{mm})\end{array}$ & $\begin{array}{l}\text { Stiffness at design } \\
\text { load* }(\mathrm{kN} / \mathrm{mm})\end{array}$ & $\alpha^{\dagger}$ \\
\hline CMP1 & 78.5 & 59 & 110 & 98.3 & 1.7 \\
CMP2 & 78.5 & 44 & 64 & 64 & 1.4 \\
CMP3 & 78.5 & 44 & 33 & 30 & 0.7 \\
CMP4 & 78.5 & 44 & 54 & 47 & 1 \\
CMP5 & 90 & 38 & 75 & 69 & 1.8 \\
WMP1 & 36.3 & 74 & 160 & 157 & 2.1 \\
WMP2 & 36.3 & 74 & 176 & 160 & 2.1 \\
WMP3 & 36.3 & 74 & 124 & & 130 \\
\hline
\end{tabular}

Fig. 15. Stress-strain relationship at micropile head.

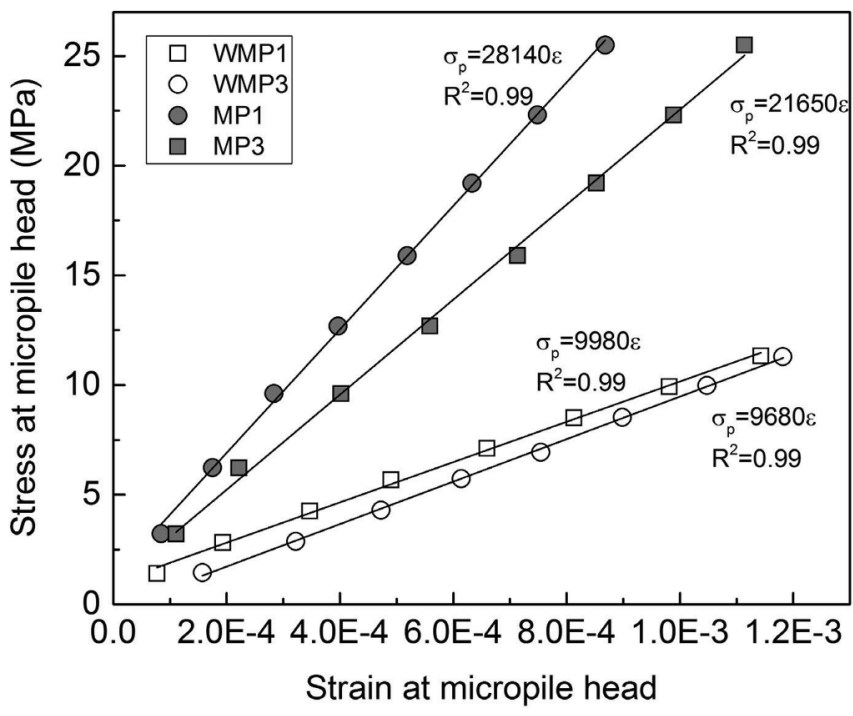

Fig. 16. Load settlement behavior of micropiled raft. ave., average.

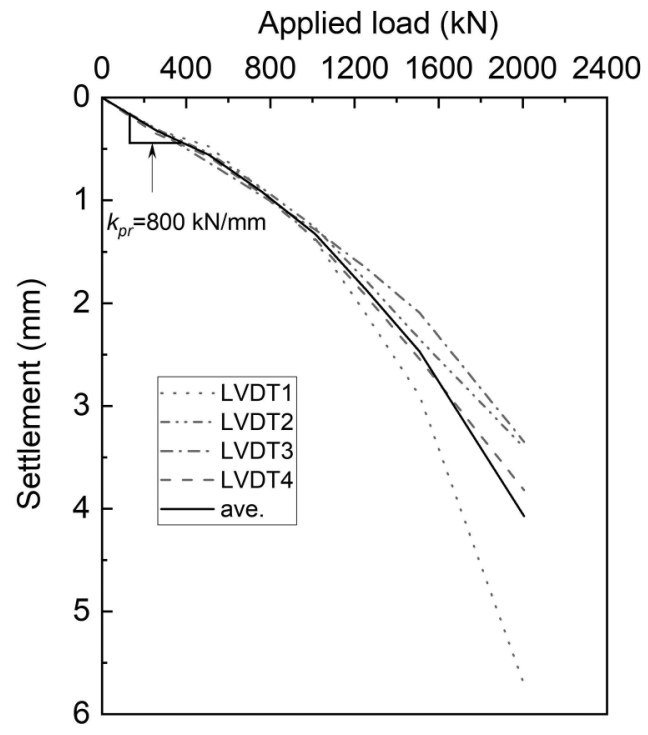

the raft during that period are plotted in Fig. 19. It can be observed that the load on the MPs and the raft is redistributed over time. The load on the raft decreases from $29 \%$ to $19 \%$ after 1 day of loading and then decreases slowly. As discussed in the
Fig. 17. Load sharing behavior of micropiles and raft: (a) carried load by micropiles and raft in micropiled raft under loading;

(b) load sharing ratio of micropiled-raft elements under loading.

(a)

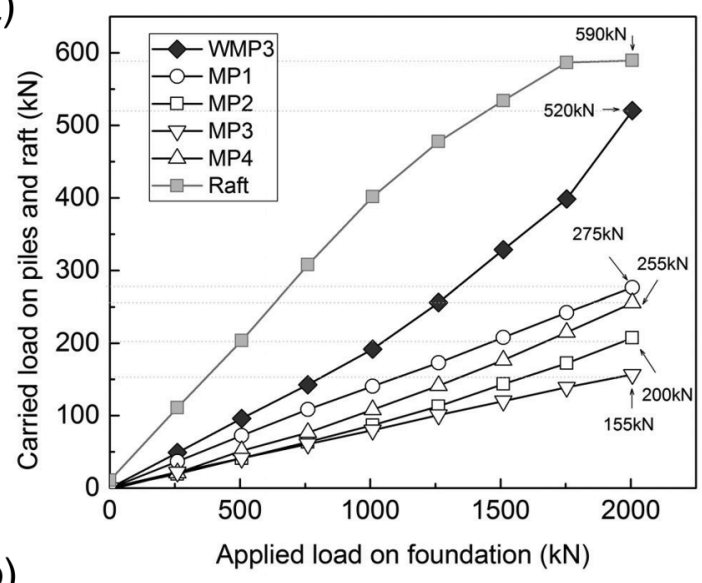

(b)

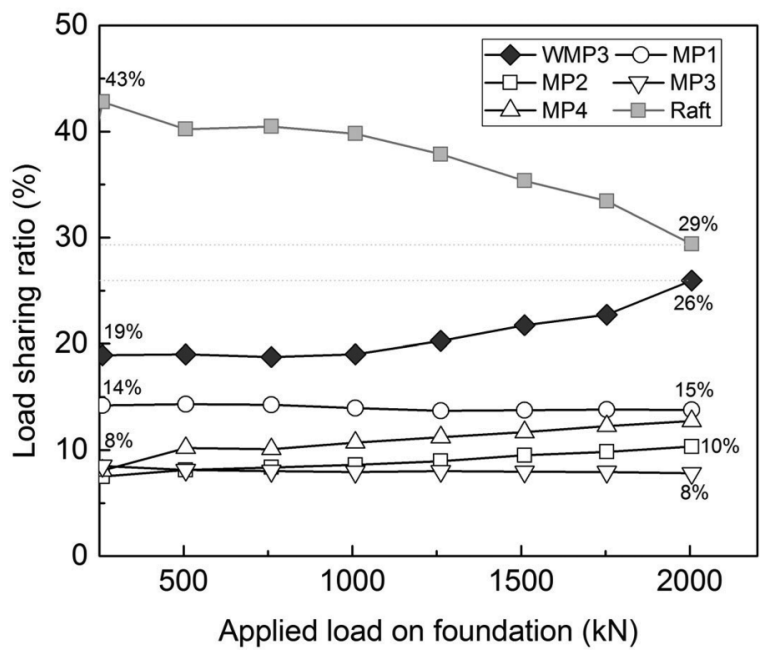

previous section, the yielding of subsoil can transfer the load from the raft during long-term monitoring.

Most of the load is transferred to the WMP, and the load sharing ratio of the WMP exceeds that of the raft. Although load redistribution occurred on the micropiled raft, the long-term load sharing measurement for the foundation elements shows that the load sharing ratio of the micropile increases with increasing axial stiffness, which is identical to the short-term measurement result. The final load sharing ratio of the WMP is $31 \%$, which is 23 times that of a type A micropile. 
Fig. 18. Comparison of unit shaft resistance along MP1 and WMP1 in single-pile and micropiled-raft loading tests: $(a)$ WMP3 $(P=200 \mathrm{kN})$; (b) WMP3 $(P=400 \mathrm{kN})$; $(c)$ MP1 $(P=200 \mathrm{kN})$; $(d)$ MP1 $(P=300 \mathrm{kN})$.

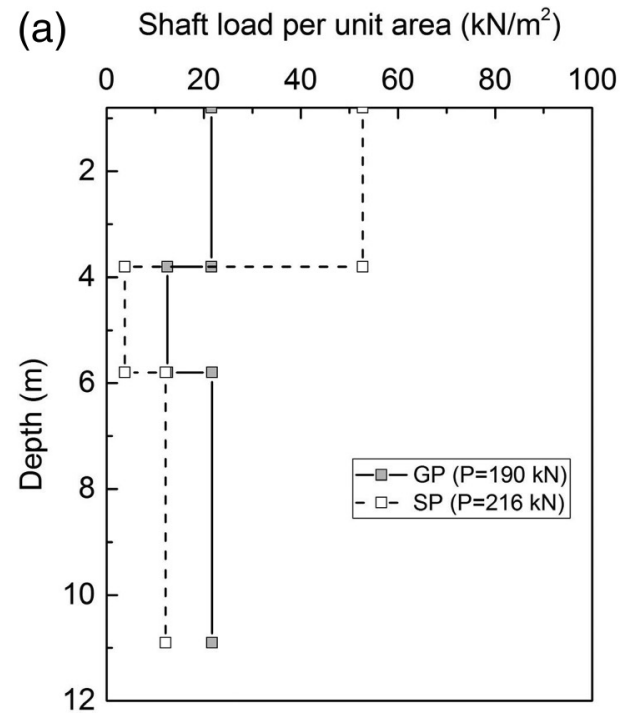

(b)

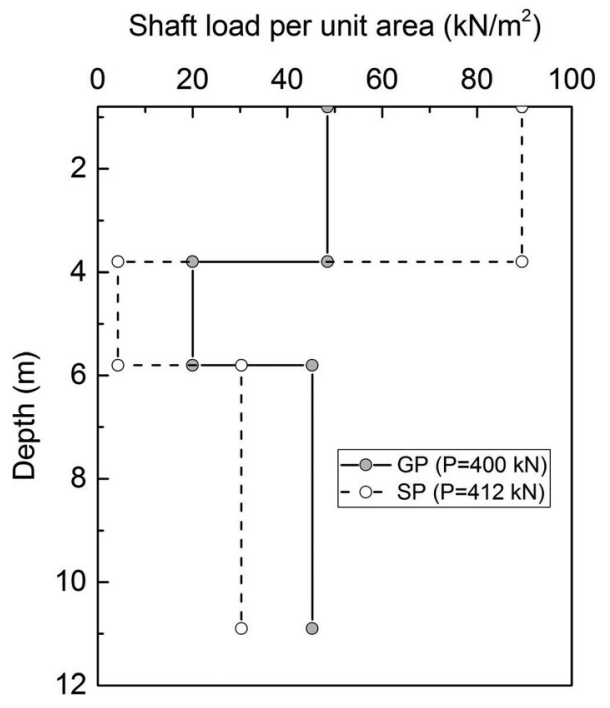

Figure 20 illustrates the load redistribution variation of the piled raft elements over 60 days. When the subsoil beneath the raft yields, the load acting on the raft is redistributed to the MPs. During the first 40 days, WMP3 carried most of the load from the raft, accounting for $40 \%$ of the total load due to the highest stiffness, while it is decreased in the final 10 days. As shown in Fig. 13, for loads higher than $650 \mathrm{kN}$, the stiffness of WMP3 decreases gradually; this stiffness reduction probably decreased the load redistribution capacity of WMP3. Similarly, at the final loading stage, MP1 and MP4 carried loads of 280 and $250 \mathrm{kN}$, respectively, and their stiffnesses were reduced by the applied loads; therefore, the load redistribution capacities of MP1 and MP4 were lower than those of MP2 and MP3. These results indicate that the micropile stiffness is reduced by the loading level as shown in Fig. 13 and the reduction of the axial stiffness of a micropile probably affects the micropile's load redistribution behavior.

\section{Discussion}

The study reveals that the WMP acting as the underpinning pile has a great underpinning performance in terms of load

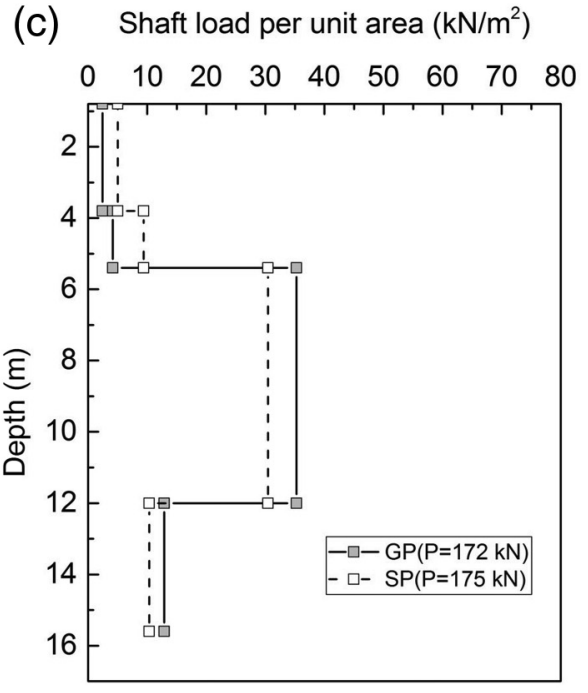

(d)

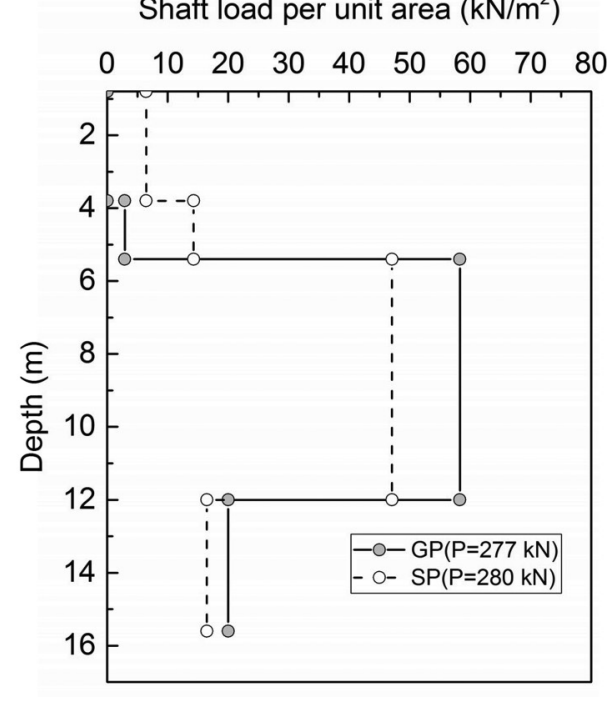

sharing capacity. The results demonstrated that the load-sharing capacity of the raft in a foundation should not be neglected as well, which is consistent with the ability of the raft to distribute $10 \%-80 \%$ of the load depending on the raft flexibility, raft width, pile length, and pile spacing (Akinmusuru 1980; Cao et al. 2004; Lee and Chung 2005; Wang et al. 2018). The stiffness of a WMP decreased monotonously with the applied load over the design load, thereby affecting the load redistribution characteristic. Therefore, in the design of foundation underpinning with WMPs, the load sharing of a WMP is suggested not to exceed the design load. In addition, the initial pressure on the existing foundation and deterioration of the existing piles due to the existing loads influence the micropile's underpinning performance (El Kamash and Han 2017, Jeong and Kim 2020), the initial load on the existing piles before installation of a waveform micropile is not considered in the study. For the proposal of an optimal design guideline for existing foundation underpinning with MPs, further studies that consider the initial and additional loading of the foundation and the configuration of the piled foundation should be conducted. 
Fig. 19. Load sharing ratio of micropiles and raft with time histories.

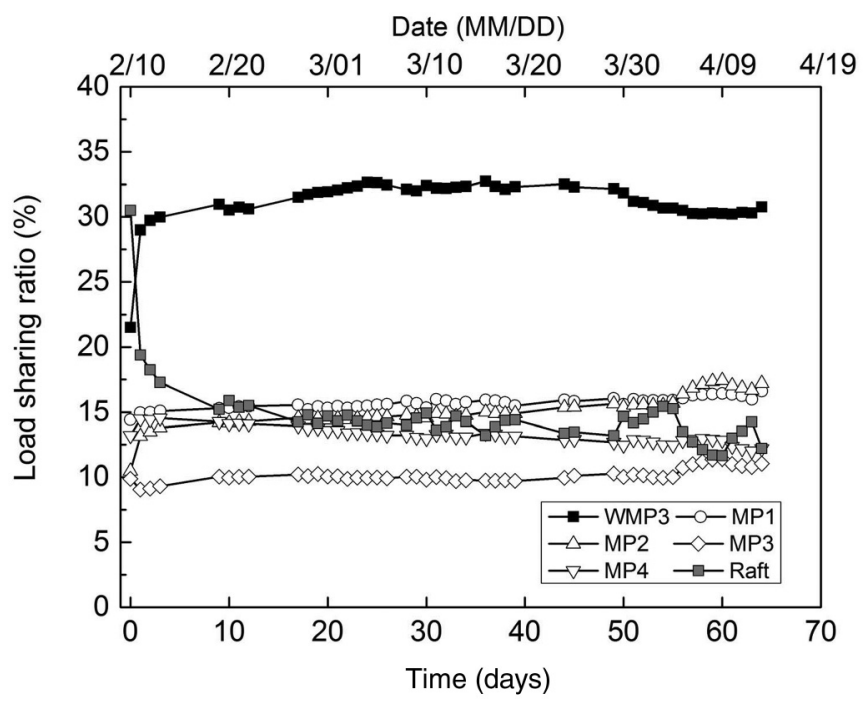

Fig. 20. Load redistribution behavior under long-term monitoring.

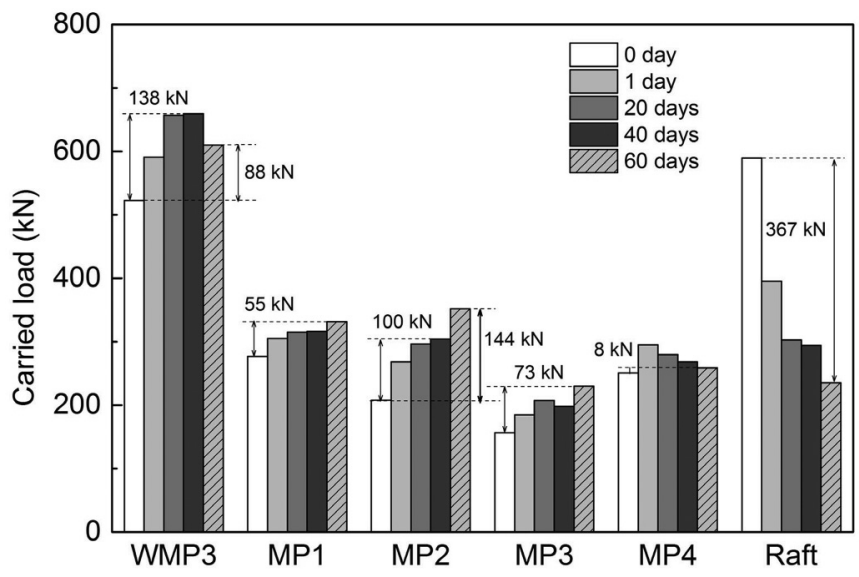

\section{Conclusions}

Here, a field study was performed to evaluate the effect of the WMP stiffness on underpinning performance in terms of the load sharing capacity. Full-scale single micropile loading tests were performed to evaluate the axial stiffnesses and the load transfer behaviors of type A MPs and WMPs subjected to compression. A loading test on a piled raft comprising four type A MPs (representing existing piles) and one WMP (acting as the underpinning pile) was performed to evaluate the effect of axial stiffness on the short- and long-term load sharing ratios of the underpinned micropiled raft. The conclusions are summarized as follows:

- The axial stiffness of a MP, which is 1-2 times that of the MP material stiffness, is highly affected by the MP slenderness ratio and the pile-soil interaction. The results of the single-pile loading tests revealed that the axial stiffness of a WMP is 2-5 times that of a type A MP even in weak soil layers. This is owing to the pile-soil interface enhancement promoted by the shear keys generated by the jet-grouting method.

- The micropiled-raft loading test under short-term monitoring showed that most of the load is carried by the raft during the initial loading stage owing to the good contact with the subsoil and the high stiffness of the raft. Thus, the load sharing influence of the raft should not be neglected in the design of pile foundations. The theoretical solution (Horikoshi and Randolph 1998) reasonably predicted the load carried by the raft. The MPs carry approximately $70 \%$ of the total load, and the load sharing ratio of the MPs increased as their axial stiffnesses increased. The WMP with the highest stiffness presented a load sharing capacity 2-3 times higher than that of a type A micropile.

- The long-term monitoring of the micropiled raft demonstrated that the load redistribution occurred when the subsoil beneath the raft yielded. The load sharing ratio of the raft under longterm monitoring reached $15 \%$, which implies that the approach proposed by Horikoshi and Randolph (1998) is not suitable for describing the long-term load sharing behavior of a piled raft. Moreover, it was found that the load redistribution capacity of a pile decreases with the reduction of the pile's axial stiffness.

\section{Acknowledgements}

This research was funded by 19RERP-B099826-05 from Residential Environment Research Program (RERP), which was funded by Ministry of Land, Infrastructure and Transport of the Korean government.

\section{References}

Abdlrahem, M.A., and El Naggar, M.H. 2020. Axial performance of micropile groups in cohesionless soil from full-scale tests. Canadian Geotechnical Journal, 57(7): 1006-1024. doi:10.1139/cgj-2018-0695.

Akinmusuru, J.O. 1980. Interaction of piles and cap in piled footings. Journal of the Geotechnical Engineering Division, 106(11): 1263-1268. doi:10.1061/AJGEB6. 0001062.

Alnuaim, A.M., El Naggar, H., and El Naggar, M.H. 2015. Performance of micropiled raft in sand subjected to vertical concentrated load: centrifuge modeling. Canadian Geotechnical Journal, 52(1): 33-45. doi:10.1139/cgj-20140001.

ASTM International. 2013. Standard test methods for deep foundations under static axial compressive load. ASTM D1143/D1143M-07(2013)e1. American Society for Testing and Materials (ASTM) International, West Conshohocken, Pa.

Bergado, D.T., and Lorenzo, G.A. 2003. Behavior of reinforced embankment on soft ground with and without jet grouted soil-cement piles. In Proceedings of the 12th Asian Regional Conference on Soil Mechanics and Geotechnical Engineering (12ARC), Singapore, 4-8 August 2013. Edited by C.F. Leung. World Scientific, Singapore. pp. 1311-1316.

Bruce, D.A. 1989. Aspects of minipiling practice in the United States. Journal of Ground Engineering, 22: 35-39.

Bruce, D.A., Cadden, A.W., and Sabatini, P.J. 2005. Practical advice for foundation design-micropile for structural support. In Geo-Frontiers Congress 2005, Austin, Tex., 24-26 January 2005. American Society of Civil Engineers, Reston, Va. pp. 1-25.

Cao, X.D., Wong, I.H., and Chang, M.F. 2004. Behavior of model rafts resting on pile-reinforced sand. Journal of Geotechnical and Geoenvironmental Engineering, ASCE, 130(20): 129-138. doi:10.1061/(ASCE)1090-0241(2004)130:2(129).

Cho, C.H. 2010. Piling engineering practice. Engineer Book.

Drbe, O.F., and El Naggar, M.H. 2015. Axial monotonic and cyclic compression behaviour of hollow-bar micropiles. Canadian Geotechnical Journal, 52(4): 426-441. doi:10.1139/cgj-2014-0052.

El Garhy, B., Galil, A.A., Youssef, A.F., and Raia, M.A. 2013. Behavior of raft on settlement reducing piles: Experimental model study. Journal of Rock Mechanics and Geotechnical Engineering, 5(5): 389-399. doi:10.1016/j.jrmge.2013.07.005.

El Kamash, W., and Han, J. 2017. Numerical analysis of existing foundations underpinned by micropile. International Journal of Geomechanics, ASCE, 17(6): 04016126. doi:10.1061/(ASCE)GM.1943-5622.0000833.

El Sawwaf, M. 2010. Experimental study of eccentrically loaded raft with connected and unconnected short piles. Journal of Geotechnical and Geoenvironmental Engineering, ASCE, 136(10): 1394-1402. doi:10.1061/(ASCE)GT.1943-5606.0000341.

FHWA. 2005. Micropile design and construction. Publication No. FHWA-NHI-05-039. Federal Highway Administration (FHWA), U.S. Department of Transportation, Washington, D.C.

Fleming, W.G.K., Weltman, A.J., Randolph, M.F., and Elson, W.K. 2009. Piling engineering. London, UK. 398 pp.

Han, J., and Ye, S.L. 2006. A field study on the behavior of a foundation underpinned by micropile. Canadian Geotechnical Journal, 43(1): 30-42. doi:10.1139/ t05-087.

Han, J., Oztoprak, S., Parsons, R.L., and Huang, J. 2007. Numerical analysis of foundation column to support widening of embankment. Computers and Geotechnics, 34 (6): 435-448. doi:10.1016/j.compgeo.2007.01.006.

Ho, C.E. 2007. Fluid-soil interaction model for jet grouting. In Grouting for Ground Improvement: Innovative Concepts and Applications. Edited by 
T.M. Hurley and L.F. Johnsen. GSP 168. American Society of Civil Engineers, Reston, Va. pp. 1-10.

Horikoshi, K., and Randolph, M.F. 1998. A contribution to optimum design of pile rafts. Géotechnique, 48(3): 301-317. doi:10.1680/geot.1998.48.3.301.

Jang, Y.-E., and Han, J.-T. 2018. Field study on axial bearing capacity and load transfer characteristic of waveform micropile. Canadian Geotechnical Journal, 55(5): 653-665. doi:10.1139/cgj-2017-0155.

Jang, Y.-E., and Han, J.-T. 2019. Analysis of the shape effect on the axial performance of a waveform micropile by centrifuge model tests. Acta Geotechnica, 14: 505-518. doi:10.1007/s11440-018-0657-2.

Jeong, S.S., and Kim, D.H. 2020. Estimation of design axial stiffness of reinforcing piles in vertical extension remodeling process using numerical computation. Engineering Structures, 214: 110623. doi:10.1016/j.engstruct.2020.110623.

KHS. 2008. Korea Highway Bridge Design Standard, explanation. Korean Society of Civil Engineering. pp. 885-887.

Kim, D.H., Kim, J.H., and Jeong, S.S. 2019. Estimation of axial stiffness on existing and reinforcing piles in vertical extension remodeled. Engineering Structures, 199: 109466. doi:10.1016/j.engstruct.2019.109466.

Lee, S.H., and Chung, C.K. 2005. An experimental study of the interaction of vertically loaded pile groups in sand. Canadian Geotechnical Journal, 42(5): 1485-1493. doi:10.1139/t05-068.

Leung, Y.F., Soga, K., and Klar, A. 2011. Multi-objective foundation optimization and its application to pile reuse. In Geo-Frontiers Congress 2011, Dallas, Tex., 13-16 March 2011. American Society of Civil Engineers, Reston, Va. pp. 75-84. doi:10.1061/41165(397)9.

Makarchian, M., and Poulos, H.G. 1996. Simplified method for design of underpinning piles. Journal of Geotechnical Engineering, ASCE, 122(9): 745751. doi:10.1061/(ASCE)0733-9410(1996)122:9(745).

MOLIT. 2013. Housing Act. Korea Ministry of Land, Infrastructure and Transport (MOLIT). 2. [In Korean.]

Ni, J.C., and Cheng, W.C. 2012. Characterising the failure pattern of a station box of Taipei rapid transit system (TRTS) and its rehabilitation. Tunnelling and Underground Space Technology, 32: 260-272. doi:10.1016/j.tust.2012.06.010.
Peplow, A.T., Jones, C.J.C., and Petyt, M. 1999. Surface vibration propagation over a layered elastic half-space with an inclusion. Applied Acoustics, 56(4): 283-296. doi:10.1016/S0003-682X(98)00031-0.

Poulos, H.G. 2001. Piled raft foundations: design and application. Géotechnique, 51(2): 95-113. doi:10.1680/geot.2001.51.2.95.

Randolph, M.F. 1983. Design of piled raft foundations. In Proceedings of the International Symposium on Recent Developments in Laboratory and Field Tests and Analysis of Geotechnical Problem, Bangkok, 6-9 December 1983. pp. 525-537.

Roberston, P.K., Campanella, R.G., Gillespie, D., and Greig, J. 1986. Use of piezometer cone data. In Use of In Situ Testing in Geotechnical Engineering. American Society of Civil Engineers, Reston, Va. pp. 1263-1280.

Shen, S., Wang, Z., Horpibulsuk, S., and Kim, Y. 2013. Jet grouting with a newly developed technology: the Twin-Jet method. Engineering Geology, 152: 87-95. doi:10.1016/j.enggeo.2012.10.018.

Shibazaki, M. 2003. State of practice of jet grouting. In Proceedings of the 3rd International Conference on Grouting and Ground Treatment, New Orleans, La., 1012 February 2003. American Society of Civil Engineers, Reston, Va. pp. 198-217.

Tsukada, Y., Miura, K., Tsubokawa, Y., Otani, Y., and You, G.L. 2006. Mechanism of bearing capacity of spread footings reinforced with micropiles. Soils and Foundations, 46: 367-376. doi:10.3208/sandf.46.367.

Wang, C.C., Jang, Y.E., Kim, S.J., and Han, J.T. 2018. Effect of waveform micropile on foundation underpinning during building remodeling with vertical extension. In Proceedings of the 5th GeoChina International Conference 2018 - Civil Infrastructures Confronting Severe Weathers and Climate Changes: From Failure to Sustainability, HangZhou, China, 23-25 July 2018. Springer, Cham. pp. 120-131.

Wang, C.C., Han, J.T., and Jang, Y.E. 2019a. Experimental investigation of micropile stiffness affecting the underpinning of an existing foundation. Applied Sciences, 9(12): 2495. doi:10.3390/app9122495.

Wang, C.C., Han, J.T., Kim, S.J., Jang, Y.E., and Park, H.J. 2019b. Model experimental study on the load sharing of piled raft on foundation underpinning. In Proceeding of the 29th International Ocean and Polar Engineering Conference, Honolulu, Hawai'i, 16-21 June 2019. pp. 2192-2197. 